Vol. 11 (1): 121-124 (2021)

\title{
THE STRUCTURE OF THE FOREST UNDER CLIMATE CHANGES AND QUESTIONS OF FORESTS MANAGEMENT IN THE WATER CATCHMENT BASINS OF THE RIVERS (SOME AREAS OF PRE-BAIKAL FOR EXAMPLE)
}

\author{
Alexander Sizykh ${ }^{1^{*}}$ \\ ${ }^{1 *}$ Siberian Institute of Plant Physiology and Biochemistry SB RAS,664033, Irkutsk, Lermontova str., 132, Russia; \\ "Corresponding Author Alexander Sizykh, e-mail: alexander.sizykh@gmail.com;
}

Received December 2020; Accepted January 2021; Published February 2021;

DOI: https://doi.org/10.31407/ijees11.116

\begin{abstract}
On the background of climate dynamics during last decade, the Baikal Region manifests considerable changes in the whole biota structure. It is seen in the structural-dynamic organization, trends of forests development due to considerable variability of vertical and horizontal structures in the coenoses. Especially this is characteristic for the forest's formation at the contact of different environments - at the boundary of zonal vegetation types and height belts in Pre-Baikal. Projects of protective forests in the basins of the rivers flowing into Lake Baikal in forests management for water protection and establishment of forests site under special protection within near-shore protective shelter belts excludes industrial forest cutting and limits other forms of forests use. Accounting of environment protection functions of forests at forests management and establishment of validity categories (not only for utility) will allow to stabilize hydroregimes and functioning of lake ecosystem in the whole.
\end{abstract}

Key words: structure of the forest, forests management, water catchment basin, Pre-Baikal areas. 